\title{
ANALISA PERBEDAAN BRAND IMAGE SITUS BERITA BERBAHASA INDONESIA ONLINE LOKAL
}

\author{
Kuspuji Catur Bagus Wicaksono \\ Jurusan Manajemen, Fakultas Ekonomi dan Bisnis, Bina Nusantara University \\ Jl. K.H. Syahdan No. 9, Kemanggisan, Palmerah, Jakarta Barat 11480 \\ gundamocil12@yahoo.com
}

\begin{abstract}
The amount of graduates and the availability of jobs are unbalanced, therefore unemployment is generalized; not only for uneducated but also those educated ones. This is supporting educational institutions to provide entrepreneurship subject for students to prepare themselves when they have no job and unemployment for the consequences. Entrpreneurial education is not about theory but also field practice that involves every parts such as educational institutions, small-scale and major business, and also government. Education that moves accordingly with the development and field practice for students to be prepared for their graduation, whether or not being an entrepreneur.
\end{abstract}

Keywords: brand image, brand awareness, brand equity, brand identity

\begin{abstract}
ABSTRAK
Perkembangan tekonologi informatika memberikan peluang bagi berbagai jenis perusahaan sebagai media penyampaian berita kepada konsumen secara langsung di depan layar internet. Setiap situs berita online mempunyai brand image yang berbeda di dalam internet walaupun mereka memasarkan produk yang identik yaitu penyampaian berita. Penulisan ini bertujuan untuk mengetahio apakah terdapat perbedaan brand image untuk situs berita berbahasa Indonesia online lokal seperti detik.com, mediaindo.co.id dan korantempo.com, berdasarkan enam faktor yaitu: benefits, attributes, cultures, values, personality dan user.Data untuk penelitian ini diperoleh dengan cara membagikan kuesioner bagi responden yang pernah dan sudah melihat ketiga situs berita yang diatas. Lalu diminta dinilai berdasarkan enam faktor tersebut untuk masing-masing situs berita berbahasa Indonesia online local. Analisa data menggunakan metode ANOVA untuk menguji perbedaan Brand Image dari masing-masing situs berita berbahasa Indonesia online lokal. Hasil dari penelitan ini menemukan bahwa terdapat perbedaan brand image antara detik.com, mediaindo.co.id dan korantempo.com terutama dari benefits, cultures dan values, tidak pada attributes sementara personality tidak layak diuji. Dengan penelitian ini, penerbit situs berita berbahasa Indonesia online lokal diharapkan untuk lebih meningkatkan brand image agar bisa memisahkan dirinya dari situs yang sejenisnya.
\end{abstract}

Kata kunci: brand image, brand awareness, brand equity, brand identity 


\section{PENDAHULUAN}

Perkembagan telekomunikasi informatika di Indonesia memberikan peluang baru bagi berbagai jenis perusahaan baik kecil maupun besar untuk menggunakannya sebagai sarana baru dalam penyampaian informasi kepada konsumen secara langsung.Penyampaian informasi dapat berupa semacam brosur yang biasa diedarkan oleh perusahaan kepada pelanggannya, dengan menggunakan medium yaitu internet, dapat disampaikan langsung kepada pelanggannya.Selain itu perusahaan penerbitan dapat menggunakannya sebagai sarana penyampain informasi yang tidak dapat dilakukan dengan menggunakan medium seperti kertas.Hal-hal seperti terbatasnya jumlah halaman, harga bahan kertas yang dibutuhkan untuk percetakan, waktu penerbitan yang kadang tidak tentu dan jumlah eksemplar yang dicetak terkadang tidak dapat memenuhi permintaan dari pembaca.Dengan adanya internet, perusahaan penerbit mulai menggunakannya sebagai sarana atau media jurnalistik untuk menyampaikan langsung informasi atau berita yang disusun oleh penerbit sendiri.

Situs berita berbahasa Indonesia online lokal seperti www.detik.com, www.mediaindo.co.id dan www.korantempo.com merupakan sebagian kecil situs yang menyajikan berita terkini yang terkenal di Indonesia.Menyusul dengan semakin maraknya situs berita sejenis yang bermunculan di Indonesia maka terjadi persaingan yang ketat. Dengan mempunyai kelebihan dan kekurangan sendiri dalam menyajikan berita melewati medium internetmaka masing-masing situs harus mempunyai suatu brand (merek) yang dapat menyaingi situs berita lainnya.

Mengenai faktor-faktor yang dapat mempengarhui suatu brand image (merek) itu sendiri menimbulkan pertanyaan-pertanyaan seperti: (1) apakah terdapat perbedaan dalam attributes (atribut) terhadap brand image (merek) dari detik.com, mediaindo.co.id dan korantempo.com; (2) apakah terdapat perbedaan dalam benefits (manfaat) terhadap brand image (merek) dari detik.com, mediaindo.co.id dan korantempo.com; (3) apakah terdapat perbedaan dalam values (nilai) terhadap brand image (merek) dari detik.com, mediaindo.co.id dan korantempo.com; (4) apakah terdapat perbedaan dalam cultures (budaya) terhadap brand image (merek) dari detik.com, mediaindo.co.id dan korantempo.com; (5) apakah terdapat perbedaan dalam personality (kepribadian) terhadap brand image (merek) dari detik.com, mediaindo.co.id dan korantempo.com; dan (6) apakah terdapat perbedaan dalam user (pemakai) terhadap brand image (merek) dari detik.com, mediaindo.co.id dan korantempo.com.

Penelitan bertujuan untuk mengetahui apakah perbedaan antara situs-situs berita online detik.com, mediaindo.co.id dan korantempo.com terhadap brand image.Dengan melihat dari atribut, manfaat, nilai, budaya, kepribadian dan pemakai dari pembaca situs berita berbahasa Indonesia online lokal tersebut.

Manfaat yand diapat dari penelitian ini adalah: (1) bagi pihak manajemen perusahaan penerbit detik.com, mediaindo.co.id dan korantempo.com dapat mengetahui pendapat dari pelanggan atau pembacanya mengenai keberadaan dari situsnya. Sehingga mungkin dapat mengambil keputusan yang lebih baik untuk membuat strategi brand dan tetap bertahan di waktu ke depan; (2) perusahaan penerbit online lainnya, dapat mempelajari dan mengembangkan strategi brand untuk masing-masing perusahaan; dan (3) akademis, menambah pengetahuan dalam emnggunakan teknologi informasi untuk berbagai kegiatan bisnis lainnya.

Surat kabar online (online newspaper) merupakan salah satu efek yang muncul dengan adanya internet. Perusahaan pencari berita menggunakannya sebagai salah satu cara untuk menembus pangsa pasar baru dengan menggunakan keunggulan dari internet itu sendiri. Kekuatan dan kelemahan yang dimiliki online newspaper bagi pembaca dari penelitian Neuberger, Tonnemacher, Biebi \& Duck (199) adalah bebas dari dikenakan biaya, penyajian berita yang lebih cepat, mempunyai arsip untuk 
setiap artikel yang telah diterbitkan kemarin, mengambil nara sumbernya tidak saja dari koran lokal tapi juga dari koran luar negeri, dengan adanya otomasi dalam pencarian dengan menggunakan search engine yang ada di dalam situs berita tersebut.

Kelemahan yang dimilikinya adalah lamanya waktu yang diperlukan untuk download berita yang diinginkan oleh pembaca, oleh karena harus tersambung dengan internet terlebih dahulu untuk bisa mengakses situs berita tersebut dan tidak semua topik artikel dibahas didalamnya juga membacanya di layar monitor tidaklah semudah dan senyaman membaca pada kertas biasa, juga membutuhkan waktu yang lama bagi pembaca untuk membiasakan diri akan online newspaper.

Brand, menurut Asosiasi Pemasaran Amerika (American Marketing Association) (Mohammed, Fisher, Jaworski \& Paddison, 2002) adalah: "A name, term, sign, symbol, or design, or a combination of them, intended to identify the goods or services of one seller or group of sellers and to differentiate them from those of competitors" (p. 508). Brand adalah nama, istilah, tanda, symbol atau gabungan dari keseluruhan, berguna untuk mengidentifikasi sesuatu produk atau jasa dari satu atau sekelompok penjual dengan pesaingnya. Berguna untuk membedakan antara penjual dan produsen, dimana penjual mempunyai kebijakan untuk menggunakan brand dari suatu produk atau jasa yang ditawarkan tanpa adanya batas waktu.Brand merupakan janji dari penjual untuk memberikan pelayanan yang sesuai dengan yang telah ditetapkan.Semakin bagus suatu brand, semakin bagus juga kualitas garansi maupun pelayanannya.

Brand itu sendiri mempunyai enam unsure pengertian (Kotler \& Armstrong,1994): (1) attributes, suatu brand membawa atribut tertentu ke alam pikiran. Sehingga brand seperti Mercedes membawa atribut berupa mahal, dikonstruksi dengan baik, tahan banting, memiliki nilai lebih bagi pemilik, nyaman dan sebagainya; (2) benefits, suatu brand tidak hanya memiliki atribut tertentu, akan tetapi mempunyai keuntungan tambahan baik secara fungsional dan emosional. Seperti contoh diatas, tahan banting lebih menuju kearah keuntungan fungsional, sementara mahal lebih menuju kearah keuntungan emosional; (3) values, suatu brand mempunyai nilai sendiri terhadap produsen, karena itu Mercedes mempunyai nilai yaitu kemampuan tinggi, keamanan, gaya hidup dan sebagainya; (4) culture, suatu brand dapat membawa budaya tertentu. Mercedes lebih membawa budaya dari Jerman yaitu terorganisasi, efisiensi dan kualitas tinggi; (5) personality, suatu brand dapat menunjukkan kepribadian tersebdiri. Mercedes bisa dilihat sebagai seorang pimpinan yang tegas atau barang yang memiliki nilai mahal; (6) user, suatu brand dapat menunjukkan pula tipe konsumen yang biasa membeli atau menggunakannya. Kita terbiasa dengan anggapan bahwa pemakai dari mobil Mercedes adalah seorang eksekutif senior, akan tetapi alangkah terkejutnya apabila ternyata pemakainya adalah seorang remaja.

Menurut Mohammed, Fisher, Jaworski \& Paddison (2002), dengan adanya medium Internet, maka brand itu sendiri terbagi menjadi dua macam bentuk yaitu: (1) online brand, suatu merek yang hanya berada dan berasal dari medium internet saja, contohnya seperti Amazon, Detik, Ojolali dan lain-lainnya; (2) offline brand, suatu merek) yang tidak hanya berada di Internet tetapi juga dari luar Internet, contohnya seperti McDonalds, Disney, Tempo dan Kompas.

Brand image menurut Kotler \& Armstrong (1994) adalah: "The set of beliefs held about a particular brand. The customer's belief may vary from true attributes based on his or her experience and the effect of selective perception, selective distortion and selective rentention" (p. 167). Merupakan sekumpulan kepercayaan yang ada pada brand tertentu. Kepercayaan konsumen dapat berbeda berdasarkan pengalaman dari persepsi, distorsi dan retensi tertentu.

Brand equity, menurut Mohammed, Fisher, Jaworski \& Paddison (2002), mempunyai definisi yaitu: "Brand Equity is reflection of a connection between the customer and brand, which leads customers to evaluate the brand differently than they evaluate competing brands" (p. 514). Merupakan 
cerminan hubungan antara konsumen dan merek dimana membawa konsumen untuk mengevaluasinya secara berbeda dengan sejenisnya.

Menurut Aaker (1996), brand identity adalah “...a unique set of brand associations that the brand strategist aspires to create or maintain. These associations represent what the brand stands for and imply a promise to customers from the organization members" (p. 68). Sekumpulan brand associations yang unik untuk digunakan oleh para pencipta strategi merek dalam membuat atau memeliharanya. Kumpulan ini menggambarkan kesan apa yang dibawa oleh suatu brand dan janji yang diberikan perusahaan kepada konsumen. Identitas dari suatu brand memberikan petunjuk, tujuan dan maksud dari brand tersebut. Brand identity bisa membantu dalam hubungan antara brand itu sendiri dengan konsumennya melalui manfaat yang diberikannya.

\section{METODE}

Waktu untuk melakukan penetlitian ini selama tujuah bulan dengan bertempat di Universitas Bina Nusantara Pascasarjana The Joseph Wibowo Center. Untuk mendapatkan sampel yang representatif terhadap populasi dan dapat menjelaskan karakterisitk dari populasi, maka dilakukan enam langkah dalam pengambilan sampel untuk penelitian yaitu: (1) mengidentifikasi target populasi, yaitu menentukan populasi spesifik yang relevan dengan tujuan dan masalah penelitian sebagai dasar pengambilan sampel. Target populasi adalah mahasiswa/i Bina Nusantara Program Pascasarjana yang aktif mencari atau melihat informasi berita melalui detik.com, mediaindo.co.id dan korantempo.com di Jakarta; (2) memilih kerangka pemilihan sampel, yang merupakan daftar elemen-elemen populasi yang dijadikan dasar untuk mengambil sampel. Melihat mayoritas mahasiswa/i program pascasarjana Universitas Bina Nusantara menggunakan layanan berita online berada di Jakarta, maka penelitian dilakukan di Jakarta; (3) menentukan metode pemilihan sampel, maka pengambilan sampel dilakukan secara acak (probability sampling); (4) menentukan prosedur penentuan unit sampel. Pemilihan berdasarkan kerangka sampel yang dilakukan melalui prosedur satu tahap yaitu pengguna layanan online, dimana pengumpulan data dilakukan sekaligus atau satu tahap melalui metode survei. Setelah itu penelitian tidak melakukan survei lagi terhadap responden yang sama; (5) menentukan ukuran sampel, hal ini penting untuk analisa statistik terhadap data. Penentuan ukuran sampel berdasarkan pertimbangan waktu dan biaya; (6) populasi yang akan dipilih dalam melakukan penelitian ini adalah populasi dari mahasiswa/i pascasarjana mengikuti program dual degree yang berdomisili di Jakarta, mempunyai tingkat pengetahuan tentang internet, membutuhkan informasi yang up-to-date setiap waktu dan mengikuti kuliah di Universitas Bina Nusantara.

Teknik sampling yang akan dilakukan mengingat bahwa jumlah mahasiswa/i yang mengikuti program pascasarjana di Universitas Bina Nusantara banyak, maka penelitian ini akan menggunakan metode sampling secara acak sederhana dari berbagai profesi, latar belakang pendidikan dan berbagai tingkatan usia.

Penelitian ini akan menggunakan jumlah sampel dari mahasiswa/i yang mengikuti program pascasarjana di Universitas Bina Nusantara sebesar lima puluh responden. Karena jumlah mahasiswa/i di dalam kelas umumnya dua puluh dari berbagai profesi, latar belakang pendidikan dan tingkatan usia. Penelitian akan menggunakan alat pengumpuan data berupa kuesioner, dimana akan dibagikan kepada mahasiswa/i pascasarjana Universitas Bina Nusantara yang mempunyai pengalam dalam menggunakan tidak hanya satu situs berita berbahasa Indonesia online lokal tapi beberapa. Dengan menggunakan menggunakan kuesioner makan akan dapat menyingkat waktu yang diperlukan dalam penelitian ini karena beberapa responden dapat mengisinya dalam waktu yang bersamaan. Bentuk dari kuesioner ini berupa pertanyaan tertutup sehingga responden hanya perlu mencari jawaan yang sudah ada tertera didalamnya dan menggunakan skala Likert antara 1 (sangat tidak setuju) dengan 5 (sangat setuju). 
Penelitian ini akan melihat melihat faktor-faktor yang mempengaruhi dari kekuatan sesuatu merek. Faktor yang mempengaruhinya seperti attributes, benefits, values, cultures, personality dan user.

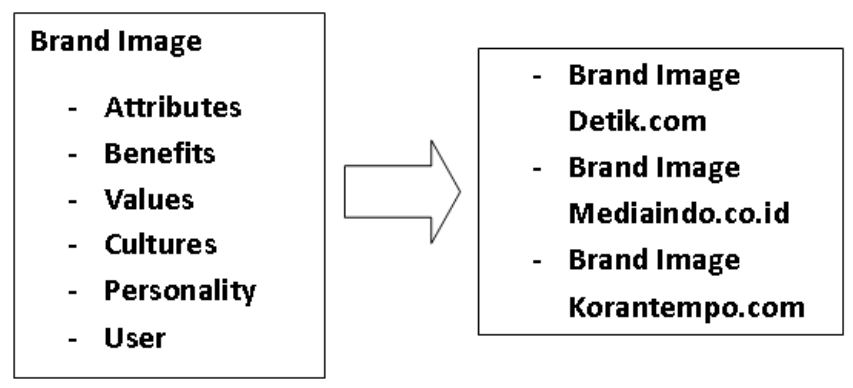

Gambar 1 Model Penelitan Merek/Brand

Dalam penelitian ini terdapat dua macam variabel yang dependen variabel dan indipenden variabel. Variabel independen penelitian adalah keenam faktor yang mempengaruhi brand yaitu: (1) attributes (X1), sesuatu yang melengkapi dari brand tersebut seperti kesan yang didapatnya. Atribut yang diukur seperti perlengkapan dari berita yang ada di situs tersebut, penampilan berita yang terbaru atau up to date pada hitungan perdetik; (2) benefits (X2), manfaat yang ditawarkan dari brand tersebut apakah sesuai dengan apa yang diharapkan konsumen. Manfaat yang diukur dari situs tersebut adalah berita yang ditampilkan bermanfaat bagi penggunalayanan online berita, memberikan layanan yang mudah dalam memberikan berita yang terbaru kepada pengguna layanan online berita yang disampaikan dengan lebih dalam atau mendetail; (3) values (X3), bilai yang ditawarkan dari brand tersebut apakah sesuai dengan apa yang diharapkan konsumen. Nilai yang ditawarkan kepada pengguna layan online berita diukur melalui pemberian atau penampilan berita yang terbaru atau uptodate per detik, dan isi berita yang diberikan atau ditampilkan oleh situs tersebut mempunyai nilai yang sepandan dengan situs tersebut; (4) cultures (X4), nilai budaya yang ditawarkan dari brand tersebut apakah sesuai dengan kenyataan yang diharapkan oleh konsumen. Pengukuruannya dapat dilihat dari budaya dari pengguna layanan berita online dengan budaya yang ingin ditampilkan dari situs tersebut dengan memberikan atau menanpilkan berita secaa online dan up-to-date; (5) personality (X5), kepribadian yang ditampilkan dari brand tersebut apakah sesuai dengan yang diharapkan oleh konsumen. Pengukurannya dilihat dari kepribadian dari situs tersebut sesuai dengan kepribadian pengguna layanan online berita yang menginginkan kecepatan dan kemudahan dalam penyampaian dan penerimaan berita; (6) user (X6), gambaran pengguna atau pemakai dari brand tersebut sesuai dengan yang diharapkan oleh konsumen; dan (7) brand (Y) adalah brand image dari situs berita berbahasa Indonesia online lokal.

Analisa statistik dalam penelitian ini menggunakan metode analisa Reliabilitas. Metode tersebut digunakan untuk melihat apakah alat ukur yang digunakan yaitu kuesioner tersebut konsisten dan tepat dalam penggunaannya. Diukur dengan suatu indeks yang dilambangkan dengan Cronbach Alpha $(\alpha)$, dimana jika $\alpha>0.7$ maka dapat dikatakan bahwa alat ukur tersebut cukup reliable. Sementara untuk pengolahan data dari kuesioner menggunakan metode Anova (Azcel, 1999) yang mempunyai definisi: "Anova is a statistical method for determining the existence of differences among several population means" (p. 374).

Metode Anova adalah metode statistik untuk menentukan adanya perbedaan antara means (rata-rata) dari beberapa populasi/sampel. Untuk penelitan ini, sampel yang digunakan adalah responden yang membaca situs berita berbahasa Indonesia online lokal yaitu untuk situs www.detik.com, www.mediaindo.co.id dan www.korantempo.com. 
Dengan menggunakan signifikan aplpha $\alpha=0.05$, maka apabila hasil yang didapat dari pengolahan data lebih besar dari 0.05 dapat dikatakan bahwa terdapat perbedaan antara populasi / sampel terhadap variabel-variabel yang diteliti. Setelah menggunakan uji ANOVA, maka penulis akan melakukan Multiple Comparisons, dengan tujuan untuk membandingkan satu sama lainnya, dalam hal ini masing-masing situs berita berbahasa Indonesia online lokal akan dibandingkan satu sama lainnya. Untuk mengetahui apakah terdapat perbedaan. Pengujian untuk penelitian ini dilakukan dengan menggunakan bantuan program Statistik SPSS.

\section{HASIL DAN PEMBAHASAN}

Hasil uji Reliabilitas dan Validitas untuk faktor-faktor yang mempengaruhi Brand Image dari www.detik.com, www.mediaindo.co.id dan www.korantempo.com dapat dilihat pada tabel dibawah ini :

Tabel 1 Hasil uji reliabilitas dan validitas faktor-faktor yang mempengaruhi brand image www.detik.com

\begin{tabular}{cc}
\hline Faktor yang mempengaruhi & Hasil Uji Reliabilitas dan \\
Brand Image & Validitas \\
\hline Attributes & 0,8225 \\
Benefits & 0,6213 \\
Cultures & $0,3587^{*}$ \\
Personality & 0,9705 \\
User & 0,9136 \\
Values & 0,6472 \\
\hline
\end{tabular}

Seperti terlihat pada Tabel 1, enam faktor yang dapat mempengaruhi Brand Image untuk www.detik.com satu diantaranya tidak mendapatkan nilai hasil uji yang layak karena dibawah nilai alpha yang dibutuhkan untuk diuji atau dianggap layak. Faktor tersebut adalah faktor cultures. Sehingga faktor tersebut tidak layak untuk diuji berikutnya.

Tabel 2 Hasil uji reliabilitas dan validitas faktor-faktor yang mempengaruhi brand image www.mediaindo.com.id

\begin{tabular}{cc}
\hline Faktor yang mempengaruhi & Hasil Uji Reliabilitas dan \\
Brand Image & Validitas \\
\hline Attributes & 0,8028 \\
Benefits & 0,7307 \\
Cultures & 0,7694 \\
Personality & $0,3294^{*}$ \\
User & 0,9132 \\
Values & 0,7500 \\
\hline
\end{tabular}

Seperti terlihat pada Tabel 2, enam faktor yang dapat mempengaruhi Brand Image untuk www.mediaindo.co.id satu diantaranya tidak mendapatkan nilai hasil uji yang layak karena dibawah nilai alpha yang dibutuhkan untuk diuji atau dianggap layak. Faktor tersebut adalah faktor personality. Sehingga faktor tersebut tidak layak untuk diuji berikutnya. 
Tabel 3 Hasil uji reliabilitas dan validitas faktor-faktor yang mempengaruhi brand image www.korantempo.com

\begin{tabular}{cc}
\hline Faktor yang mempengaruhi & Hasil Uji Reliabilitas dan \\
Brand Image & Validitas \\
\hline Attributes & 0,7969 \\
Benefits & $0,0960^{*}$ \\
Cultures & 0,8341 \\
Personality & $0,1327^{*}$ \\
User & 0,9472 \\
Values & 0,7956 \\
\hline
\end{tabular}

Seperti terlihat pada Tabel 3, enam faktor yang dapat mempengaruhi brand image untuk www.korantempo.com, dua di antaranya tidak mendapatkan nilai hasil uji yang layak karena dibawah nilai alpha yang dibutuhkan untuk diuji atau dianggap layak. Faktor tersebut adalah faktor benefits dan personality. Sehingga kedua faktor tersebut tidak layak untuk diuji berikutnya.

Dilihat dari hasil yang didapat maka dari keenam faktor yang diuji kelayakannya hanya satu faktor yang tidak akan dimasukkan ke dalam pengujian ANOVA yaitu personality. Karena hanya personality untuk www.detik.com yang memiliki nilai yang layak, sedangkan untuk www.mediaindo.co.id dan www.korantempo.com memiliki nilai yang tidak layak atau dibawah Alpha Cronbach 0,6. Pengujian ANOVA tersebut setidaknya harus membandingkan dua dari tiga situs berita berbahasa Indonesia online lokal yang akan diuji.

Setelah melakukan uji Reliabilitas dan Validitias untuk mengetahui variabel-variabel yang layak, maka langkah selanjutnya adalah melakukan uji ANOVA dengan tujuan melihat apakah terdapat perbedaan dalam Brand Image antara www.detik.com, www.mediaindo.co.id dan www.korantempo.com. Pengujian ini menggunakan uji ANOVA karena sesuai dengan tujuan penulisan ini yaitu penggambaran mengenai apakah ada perbedaan dalam Brand Image antara situs berita berbahasa Indonesia online lokal tersebut.

Dengan menggunakan uji ANOVA, diperoleh hasil bahwa tidak terdapat perbedaan dalam hal Attributes terhadap Brand Image antara www.detik.com, www.mediaindo.co.id dan www.korantempo.com. Oleh karena masing-masing situs berita berbahasa Indonesia online lokal mempunyai berbagai macam topik berita baik dalam negeri maupun luar negeri, segmentasi berita yang dimiliki seperti untuk IT, keuangan, perbankan dan sebagainya. Pada pengujian Benefits, diperoleh hasil bahwa terdapat perbedaan dalam hal tersebut diantara ketiga situs berita berbahasa Indonesia online lokal tersebut.

Manfaat yang diperoleh pengguna berbeda-beda untuk masing-masing situs berita online seperti, www.detik.com memberikan berita yang diurutkan berdasarkan terbarunya melalui wkatu diperolehnya berita tersebut. Untuk www.mediaindo.co.id, karena situs berita tersebut merupakan bagian dari surat kabar yang diterbitkan dengan menggunakan nama Media Indonesia setiap hari. Sebahagian besar berita berasal dari surat kabar tersebut, sehingga bermanfaat bagi pembaca yang tidak sempat membeli maupun membacanya, dapat langsung menggunakan internet untuk mengakses situs tersebut dengan tujuan melihat berita yang termuat didalamnya.

Sementara www.korantempo.com merupakan bagian dari surat kabar yang diterbitkan dengan menggunakan nama yang sama yaitu Koran Tempo, dimana surat kabar tersebut juga merupakan bagian dari majalah Tempo yang diterbitkan seminggu sekali. Manfaat yang diperoleh bagi konsumennya adalah dalam hal penyampaian berita yang lebih mendetail dibandingkan yang lainnya. Tersedia juga fasilitas keanggotaan untuk pembacanya dengan membayar iuran bulanan dan 
memperoleh akses untuk berita yang ada di dalam situs tersebut dimana tidak saja dari korantempo.com akan tetapi juga dari surat kabar itu sendiri dan majalahnya.

Berikutnya adalah pengujian dalam hal cultures terhadap brand image dan menunjukkan terdapat perbedaan diantara ketiga situs berita berbahasa Indonesia online lokal tersebut. Penggunaan bahasa Indonesia yang lebih kental dan banyak di www.detik.com dan www.korantempo.com itu sendiri dan juga berita yang berasal dari dalam negeri. Berbeda dengan www.mediaindo.co.id yang juga menawarkan berita yang berasal dari luar negeri atau internasional. Berbeda untuk pengujian user, hasil yang diperoleh menunjukkan bahwa tidak ada perbedaan dalam hal tersebut untuk ketiga situs berbahasa Indonesia online lokal. Umumnya para user yang selalu ingin mencari berita yang terbaru dengan mudah dan cepat, tidak memandang pengalaman kerja atau profesi yang dimiliki oleh pembaca, karena memang ditujukan untuk kalangan umum. Pembaca tidak mempedulikan topik berita yang ada maupun tidak ada, yang penting bahwa situs berita tersebut menyampaikan berita secara lugas, cepat dan tepat waktu.

Pengujian dalam hal values untuk brand image ketiga situs berita berbahasa Indonesia online lokal yaitu www.detik.com, www.mediaindo.co.id dan korantempo.com. Perbedaan dalam hal values untuk masing-masing situs berita online dapat dilihat dari asal atau sumber pada situs berita online tersebut. Karena www.detik.com berasal dari laporan wartawan yang terjun ke lapangan sehingga berita yang disampaikan mencerminkan apa yang terjadi saat itu juga. Sedangkan www.mediaindo.co.id sebahagian besar berasal dari laporan wartawan juga dari surat kabar yang diterbitkan dengan memakai nama yang sama sehingga tercemin setidaknya bahwa beritanya berasal dari satu sumber tapi beberapa sumber dan penjelasannnya juga.

\section{PENUTUP}

Simpulan yang diperoleh dari penelitian ini adalah terdapat perbedaan dalam hal Brand Image yang dimiliki oleh situs berita berbahasa Indonesia online lokal seperti www.detik.com, www.mediaindo.co.id dan www.korantempo.com, walaupun situs tersebut merupakan situs yang sejenis, yaitu menawarkan atau menyajikan berita baik luar maupun dalam negeri melalui media internet. Perbedaannya dapat dilihat dari benefits, manfaat yang didapat bagi pembaca situs berita online tersebut. DImana setiap situs memberikan benefits yang berbeda satu sama lain seperti adanya keanggotaan untuk melihat topik berita tertentu dengan lebih detail serta memperoleh berita atau informasi lebih cepat dan penyampaiannya secara lugas. Untuk kategori benefits, situs berita online www.detik.com memperoleh nilai dari responden lebih tinggi dari yang lain sehingga terlihat bahwa situs tersebut memberikan Benefits lebih banyak bagi para konsumennya. Seperti berita terbaru dalam hitungan perdetik, nama dari situs tersebut yang mudah diingat dan dimasukkan ke dalam mesin pencari di internet, juga kemudahan dalam pengaksesan bagi pembacanya.

Perbedaan kedua yang dapat dilihat adalah cultures, dimana bahasa jurnalistik yang digunakan didalam masing-masing situs berita online berbahasa Indonesia online lokal tersebut berbeda. Seperti dalam penyampaian berita secara cepat dan lugas dari sumber terpercaya, penggunaan media internet dalam penyampaian berita mencerminkan pemahaman teknologi yang maju oleh karena kemudahan dalam pengaksesan. Mengingat bahwa budaya dari penduduk Jakarta yang menginginkan serba instan, cepat karena waktu yang sangat berharga, sehingga mendorong situs berita berbahasa Indonesia online lokal untuk menyajikan dalam waktu yang cepat dan tidak merepotkan pembacanya dalam mengaksesnya. Sehingga mereka bisa mencari informasi melalui internet karena mudah didapat dan digunakan bagi mereka yang sudah berpengalaman dalam menggunakan maupun mengetahui mengenai internet. Lagi-lagi situs berita www.detik.com memperoleh nilai dari responden lebih tinggi 
dari yang lain sehingga terlihat bahwa situs tersebut memberikan cultures lebih banyak bagi konsumennya dibandingkan yang lainnya.

Perbedaan ketiga yang dapat dilihat adalah values, nilai yang ditawarkan dalam harapan yang diinginkan oleh pembaca situs berita online tersebut. Dalam hal penyajian beritanya secara cepat dan lugas, kelengkapan historis yang dimiliki oleh situs berita online tersebut. Diantara ketiga situs berita berbahasa Indonesia online lokal, maka www.mediaindo.co.id memperoleh nilai lebih tinggi dibandingkan dengan situs lainnya, karena situs tersebut berasal dari perusahaan penerbit surat kabar yang mempunyai pengalaman lebih lama dibandingkan lainnya.

Tidak terdapat perbedaan dalam hal attributes dan user, karena pembaca berita online tersebut menganggap bahwa setiap situs berita online tersebut memiliki attributes, kelengkapan yang tidak berbeda antara satu sama lainnya dan tidak ada pengecualian untuk jenis pembaca situs berita online. Selain itu semua user dapat menikmati atau membaca berita yang ada di situs berita online tersebut, tidak ada pengecualian baik dari latar belakang pendidikan maupun lainnya.

Dengan kesimpulan yang diperoleh, maka bagi pihak manajemen dalam sebuah perusahaan penerbitan surat kabar yang ingin menggunakan sara internet sebagai salah satu sarana untuk menyampaikan berita dan informasi kepada pembacanya, maka sebaiknya menfokuskan pada tiga faktor yaitu benefits, cultures dan values yang akan diberikan kepada pembacanya melalui situs berita berbahasa Indonesia online lokal yang akan dibuatnya.

Saran dari penelitian ini adalah bagi masing-masing situs berita berbahasa Indonesia online lokal harus masing-masing meningkatkan brand image-nya sehingga dapat menghasilkan perbedaan yang lebih menonjol antara satu sama lainnya. Dapat dilakukan dnegan memberikan prioritas pada benefits, manfaat yang akan diperoleh bagi para calon pembaca yang mengakses situs tersebut. Dalam hal cultures, budaya yang ingin dibawa ke dalam situs berita online tersebut, yang mengikuti budaya dari pembaca yang berada di ibukota Jakarta, dan values, nilai yang ingin diberikan oleh situs berita berbahasa Indonesia online lokal tersebut, sehingga memberikan nilai lebih kepada calon pembaca untuk mengaksesnya. Dengan memusatkan perhatian kepada tiga faktor tersebut, maka diharapkan pihak manajemen dapat mengambil langkah yang tepat dalam pembuatan situs berita online dengan melihat pada faktor-faktor tersebut.

\section{DAFTAR PUSTAKA}

Aaker, D. A. (1996). Building strong brands. New York, America: The Free Press.

Azcel, A. D. (1999). Complete business statistic (4th ed.). Singapore: McGraw-Hill.

Cormer, D. E. (2001). Computer networks and internets with internet applications (3rd ed.). Prentice Hall.

Kotler, P. (2000). Marketing management. Prentice-Hall International.

Kotler, P., \& Armstrong, G. (1994). Principles of Marketing (6th ed.). Prentice-Hall International.

Mohammed, R., Fisher, R. J., Jaworski, B. J., \& Paddison, G. (2002). Internet marketing: Building advantage in a networked economy. Berkeley, California: McGraw-Hill/Irwin. 
Neuberger, C., Tonnemacher, J., Biebi, M., \& Duck, A. (1999). Online the future of newspapers? Germany dailies on the world wide web. Diakses dari http://www.asusc.org/jcmc/vol4/issue1/neuberger.html

Santoso, S. (2001). SPSS versi 10: Mengolah data statistik secara profesional. Jakarta: Gramedia Pustaka Utama.

\section{RIWAYAT PENULIS}

Kuspuji Catur Bagus Wicaksono lahir di kota Jakarta pada tanggal 12 Desember 1977. Penulis menamatkan pendidikan S1 di Universitas Trisakti dalam bidang Manajemen Internasional pada tahun 2000 dab S2 di Universitas Bina Nusantara dalam bidang Manajemen Informasi pada tahun 2002. Saat ini bekerja sebagai dosen di Unversitas Bina Nusantara dari tahun 2005. 